\title{
Diagnosis of sustainable collaboration in health promotion - a case study
}

\author{
Mariken TW Leurs*1,6, Ingrid M Mur-Veeman², Rosalie van der Sar ${ }^{3,6}$, \\ Herman P Schaalma ${ }^{4}$ and Nanne K de Vries $^{5}$
}

\begin{abstract}
Address: ${ }^{Y}$ Youth Department, Netherlands Organization for Health Research and Development, P.O. Box 93245; 2509 AE The Hague, The Netherlands, ${ }^{2}$ Health Policy and Economics Department, University Maastricht, PO Box 616, 6400 MD Maastricht, The Netherlands, ${ }^{3} \mathrm{Health}$ Promotion Department, Netherlands Organization for Health Research and Development P.O. Box 93245; 2509 AE The Hague, The Netherlands, ${ }^{4}$ Psychology Faculty, University Maastricht, PO Box 616, 6400 MD Maastricht, The Netherlands, ${ }^{5}$ Health Promotion Department, University Maastricht, PO Box 616, 6400 MD Maastricht, The Netherlands and ${ }^{6}$ Regional Public Health Service Maastricht, The Netherlands

Email: Mariken TW Leurs* - mariken_justin@ hotmail.com; Ingrid M Mur-Veeman - i.mur@beoz.unimaas.nl; Rosalie van der Sar - rosalievandersar@hotmail.com; Herman P Schaalma - herman.schaalma@psychology.unimaas.nl; Nanne K de

Vries - n.devries@gvo.unimaas.nl

* Corresponding author
\end{abstract}

Published: 7 November 2008

BMC Public Health 2008, 8:382 doi:10.1 I86/147/-2458-8-382
Received: 8 April 2008

Accepted: 7 November 2008

This article is available from: http://www.biomedcentral.com/I47I-2458/8/382

(C) 2008 Leurs et al; licensee BioMed Central Ltd.

This is an Open Access article distributed under the terms of the Creative Commons Attribution License (http://creativecommons.org/licenses/by/2.0), which permits unrestricted use, distribution, and reproduction in any medium, provided the original work is properly cited.

\begin{abstract}
Background: Collaborations are important to health promotion in addressing multi-party problems. Interest in collaborative processes in health promotion is rising, but still lacks monitoring instruments. The authors developed the Dlagnosis of Sustainable Collaboration (DISC) model to enable comprehensive monitoring of public health collaboratives. The model focuses on opportunities and impediments for collaborative change, based on evidence from interorganizational collaboration, organizational behavior and planned organizational change. To illustrate and assess the DISC-model, the 2003/2004 application of the model to the Dutch wholeschool health promotion collaboration is described.
\end{abstract}

Methods: The study combined quantitative research, using a cross-sectional survey, with qualitative research using the personal interview methodology and document analysis. A DISCbased survey was sent to 55 stakeholders in whole-school health promotion in one Dutch region. The survey consisted of 22 scales with 3 to 8 items. Only scales with a reliability score of 0.60 were accepted. The analysis provided for comparisons between stakeholders from education, public service and public health.

The survey was followed by approaching 14 stakeholders for a semi-structured DISC-based interview. As the interviews were timed after the survey, the interviews were used to clarify unexpected and unclear outcomes of the survey as well.

Additionally, a DISC-based document analysis was conducted including minutes of meetings, project descriptions and correspondence with schools and municipalities.

Results: Response of the survey was $77 \%$ and of the interviews $86 \%$. Significant differences between respondents of different domains were found for the following scales: organizational characteristics scale, the change strategies, network development, project management, willingness to commit and innovative actions and adaptations. The interviews provided a more specific picture of the state of the art of the studied collaboration regarding the DISC-constructs. 
Conclusion: The DISC-model is more than just the sum of the different parameters provided in the literature on interorganizational collaboration, organization change, networking and settingapproaches. Monitoring a collaboration based on the DISC-model yields insight into windows of opportunity and current impediments for collaborative change. DISC-based monitoring is a promising strategy enabling project managers and social entrepreneurs to plan change management strategies systematically.

\section{Background}

Collaborations and partnerships are elemental to health promotion in general and of school health promotion in particular, when promoting healthy life-styles using multi-interventino approaches [1-3]. Intersectoral collaboration where people from different domains, cultures and jargon are expected to work together is not without challenges [4-6]. Interest in the process and prerequisites of collaboration in organizing (school) health promotion, is rising $[7,8]$. Underlying theories and principles of organization change are widely available from other sectors [9-12]. However, the scientific literature does not provide comprehensive monitoring instruments focusing on the specific pitfalls and opportunities in collaborative processes towards (school) health promotion.

In this article we delineate the DIagnoses of Sustainable Collaboration (DISC) model [13]. The DISC-model is meant to describe the state of affairs of a health promotion oriented collaboration at a certain moment in time, aiming to reveal opportunities and impediments for change. A thorough analysis of the current status of the collaboration supports the selection of suitable change strategies to enhance the development of the collaboration[14].

\section{Schoolbeat}

To illustrate and assess the DISC-model, the 2003 application of the model to the Dutch schoolBeat collaboration is described. The schoolBeat-partners aimed to build a coordinated multi-organization strategy supporting tailored whole-school health promotion [15]. The development of schoolBeat commenced in 2001 when five regional health-promoting agencies joined forces in the south of the Netherlands. The five key-players came from the areas of addiction, mental health, public health, youth care and social welfare [16]. With the recruitment of a researcher and project manager, financed by a national four-year grant by the Healthy Living program of the Netherlands Organization for Health Research and Development, the project advanced in Spring 2002 [15]. This schoolBeat-strategy is based on sharing whole-school health promotion advisory tasks between organizations from the public health, welfare, mental health and addiction domains. In ten years, schoolBeat aimed to reduce risk behaviours among youth (4-19 years) in the Maas- tricht region. The projects midterm objectives (2005) focused on establishing sustainable collaboration among schools, health promoting agencies and local authorities. The number and quality of tailored health promotion activities should also be increased in this period. In order to pursue these objectives a systematic plan of coordinated support for tailored school health promotion policy was developed. The plan was based on the principles of intervention mapping [17] and tailored to the possibilities and pitfalls of the educational system and the health system in the Netherlands. Forms of action research were used in combination with literature reviews and expert consultations in writing the plan [18-20]. However, programs cannot be developed based on expertise and authority alone. It requires full participation of all stakeholders [21]. Hence, the development of schoolBeat included participation of stakeholders from the health, welfare, and education sectors and the government. This is a common type of collaboration in school health promotion in the Netherlands [22-25].

The DISC-study was part of the four-year grant for the development and evaluation of the schoolBeat-strategy. The contribution of the stakeholders to the schoolBeatcollaboration itself was not covered by the national grant. This was paid for by the stakeholder-organizations themselves following their tasks and responsibilities in the area of school health promotion.

As it was the first time the DISC-model was used in its current form, exploring its usability for assessing intersectoral collaboration in general was the primary aim of this study. In this paper we will specifically address the differences indicated by DISC-based comparisons between the sectors participating in the schoolBeat-collaboration: schools, support organizations and governments

\section{The DISC-model}

Effective health promotion alliances require management skilled in networking, knowledge-sharing and partnership creation and support [26-28]. Assessment of a potential or existing health promotion collaboration, in addition to needs assessment in the health promotion setting, is required to enable systematic planning of strategies for program development, implementation and maintenance $[29,30]$. Hence, management skills regarding ongoing 
evaluation of the collaborative status of the alliance are needed as well $[11,14]$.

The DISC model was developed to systematically support such evaluations. The model goes beyond the more traditional evaluation models used in health promotion, which focus primarily on the implementation and effects of single intervention programs. DISC describes factors affecting the evolution of collaboration. The model focuses on the interaction between project management, collaborating partners as a whole (i.e. collaborative support), project organization and factors in the wider context, and their impact on the subject of the collaborative process. At the level of the 'collaborative support' the model distinguishes between 'perceptions', 'intentions' and 'actions'. Each construct is assessed by a set of indicators. The term 'sustainable' refers to the aim of the collaboration to continue after the initial project phase has ended, without committing themselves to an ever lasting collaboration. If collaborations do not aim for continuation, DISC analysis is not appropriate.

Figure 1 presents the DISC-model; the DISC-constructs are delineated in Table 1. Generally, the DISC-model links assessments of the collaborative process directly to the real-life context in which the intervention or set of interventions is developed, implemented and, if successful, maintained. This makes the model appropriate for case study designs as described by Yin and advocated by others [31-33].

The model is based on a literature review and initial experiences with an explorative research model introduced in the early 1990's. The initial model was used in multiple case studies in collaborative home care services in the Netherlands $[34,35]$. The model proved to be valuable to case study research in home care and in shared care studies [36]. As no suitable models from the area of health promotion were detected, and experience in the research group with this care-model already existed, the caremodel was used as a starting point. It should be noted that the initial model focuses on general elements important to interorganizational collaboration, organizational behavior and planned organizational change $[3,11,14,37]$. The assumption is that the collaboration puts a strain on the participating organizations and requires them to change in a minor and in specific areas in a major way. This is based on the open systems school of thinking: organizations are social systems that interact with their environment aiming to meet internal needs as well as needs of the environment [38,39].

Ruland and colleagues slightly modified the initial model to be applicable to organizations involved in health promotion alliances, with a strong focus on formalization
[40]. However, true formalization of a sustainable alliance is a phase many health promotion alliances may never reach or wish to reach. Like Ruland and colleagues, often reviews and studies on collaborations seem to fail to recognize that the goal of their collaborative process (sustainable coordinated health promotion) may change under influence of the collaborative process itself. Gillies already recommended flexibility in project planning and working procedures, to enable the management of environmental changes at different levels [41]. This can be taken one step further by allowing for adaptations to the project or strategy itself as a result of the collaborative processes, influenced among other things by environmental changes. Hence, the focus of the collaboration may 'change color' during the transition period from idea to formalized activity. This is reflected in color change of the bar at the bottom of the DISC-model. We also added the indicator 'research power' in the context-construct. This was based on the finding that the absence or presence of scientific evaluation influences the level of successful implementation of care innovations in organizations [42].

In this article we describe the application of the model to the initial phase of the schoolBeat collaboration to delineate its possibilities and limitations in enhancing intersectoral collaborative processes in health promotion. The study was conducted in the 2003-2004 period, one year after the initiation of the collaborative process.

\section{Methods}

The study combined quantitative research (a cross-sectional survey), qualitative research (structured interviews) and document analysis. The primary aim of the study was to pilot the DISC-model as an instrument for diagnosing opportunities and impediments of collaborative processes. The practical aim of the pilot for those involved in the alliance diagnosed was to identify differences between groups of stakeholders (i.e. education, health/welfare and government) in school health promotion regarding the DISC-constructs (see Table 1), resulting in recommendations for improving the collaborative process itself.

\section{Sample}

A questionnaire was sent to fifty-five schoolBeat-stakeholders identified by the project management: 19 people from the education domain, 19 people from the support organizations and 17 from municipalities and provincial government. The main criterion for stakeholder selection was a basic understanding of the collaboration studied, expected by the project management. As questionnaires and interviews took place only one year after the start of the schoolBeat-project, no professionals had dropped out at the time of the study. About half of the people from the education domain were active as pupil care coordinators 
Table I: General description of constructs and indicators of the DISC-model

\begin{tabular}{|c|c|c|}
\hline Construct & Scales & General description per construct \\
\hline External factors & $\begin{array}{l}\text { 1) Policy and regulations } \\
\text { 2) Attitudes of financing bodies }\end{array}$ & $\begin{array}{l}\text { The collaborative process is influenced by a number of } \\
\text { factors that are beyond the control or influence of the } \\
\text { alliance itself: } \\
\text { I) Clear, preferably inter-sectoral policies, laws and } \\
\text { regulations providing challenging and sound goals for } \\
\text { health promotion may enhance the collaborative } \\
\text { process. Limiting factors may be diffuse borders } \\
\text { between policy domains, contradicting policies of } \\
\text { different public sectors and policies focusing on the } \\
\text { transformation of public organizations into private } \\
\text { enterprises. } \\
\text { 2) An encouraging and accommodating attitude of } \\
\text { financing bodies and commitment to provide the } \\
\text { necessary funding over a longer period to prevent a } \\
\text { brain drain from starting during the initial } \\
\text { developmental phase, supports the collaborative } \\
\text { process. }\end{array}$ \\
\hline
\end{tabular}

\section{Context}

3) Existing alliances

4) Characteristics of organizations

5) Research power

6) Direct relevant governmental policies
The collaborative process evolves in a context which can be influenced by the partners themselves When parties have more positive experiences with each other in previous collaborative processes, need less energy for internal changes, have more research power and feel more supported by policies which they can influence as well, they are more open to sustainable collaborative process supporting intersectoral health promotion.

\section{Change Management}

\section{7) Vision}

8) Innovation perspective

9) Change strategies

10) Network development
The aspired change requires management by one or a small group of leaders.

In order to establish a successful collaboration individual and collective leadership skills are necessary to guide the developmental process. Change management strategies should fit the chosen innovation perspective and be supportive of the health promotion subject. The most relevant actors are included, and where missing, this will be accomplished by extending the network of the leaders of the collaborative process.

\author{
Project - management \\ II) actors, task \& structure \\ (who, what and how)
}

During the development and initial implementation phase the collaborative process is dealt with as a project in a project management structure.

This includes deciding who are the actors in the project, what do they need to do and how do they operate (planning, procedures, evaluation, communication, etcetera). This project management structure fades out when the subject of the collaborative process is (close to) being integrated in regular work and the alliance becomes selfsupportive.

\begin{tabular}{lll}
\hline $\begin{array}{c}\text { Support } \\
\text { based on intersectoral collaboration }\end{array}$ & $\begin{array}{l}\text { Perceptions: } \\
\text { I2) Goals }\end{array}$ & $\begin{array}{l}\text { The collaborative support can be assessed on the levels } \\
\text { of perceptions, intentions and actions of the parties } \\
\text { involved. }\end{array}$ \\
& I3) Importance/Win-win & Intersectoral collaboration evolves more smoothly \\
when participating organizations share goals and & interests, perceive positive outcomes supportive of \\
i5) Involvement & their own goals, are able to reach consensus on the \\
& goal of the collaborative process and are of the & opinion that the most relevant parties are involved in \\
& & the collaborative process.
\end{tabular}


Table I: General description of constructs and indicators of the DISC-model (Continued)

\begin{tabular}{|c|c|c|}
\hline & $\begin{array}{l}\text { Intentions to: } \\
\text { 16) Mutual trust } \\
\text { 18) Commitment } \\
\text { 19) Change }\end{array}$ & $\begin{array}{l}\text { Parties involved should start with the intention to } \\
\text { trust each other (if not present, this needs to be } \\
\text { worked on first), the intention to commit } \\
\text { themselves to the collaborative process and its } \\
\text { subject and the intention to make changes within } \\
\text { ones own organization, if needed, in favor of the } \\
\text { collaborative process. }\end{array}$ \\
\hline & $\begin{array}{l}\text { Actions: } \\
\text { 20) Innovative actions } \\
\text { a) Adaptations } \\
\text { b) Reallocation of resources } \\
\text { 2I) Formalizations }\end{array}$ & $\begin{array}{l}\text { The collaborative process may induce a wide variety } \\
\text { of actions, varying from the implementation to major } \\
\text { innovations within ones own organizations to the } \\
\text { inclusion of relatively minor adaptations of regular } \\
\text { procedures. The actions may involve a reallocation } \\
\text { of resources as well. Whatever actions result from a } \\
\text { collaborative process, it is important that these are } \\
\text { formalized in order to enhance sustainability. The } \\
\text { level of formalization needed depends mainly on the } \\
\text { type of action itself. }\end{array}$ \\
\hline Coordinated Health Promotion & $\begin{array}{l}\text { 22) From idea and project management to } \\
\text { formalized regular work }\end{array}$ & $\begin{array}{l}\text { The collaborative process influences the } \\
\text { development of the coordinated (school) health } \\
\text { promotion and supports the move towards } \\
\text { sustainability (goal): } \\
\text { Under continuous influence of the collaborative } \\
\text { process, an idea is elaborated and develops into } \\
\text { regular working routine being formalize. During this } \\
\text { process the subject of the collaborative process } \\
\text { evolves: it 'changes color' under influence of the } \\
\text { collaborative process itself. }\end{array}$ \\
\hline
\end{tabular}

in their schools for secondary education with responsibilities for school health, with the other half fulfilling management positions in primary or secondary educations responsible for preventive pupil care. From the support organizations CEO's, members of the schoolBeat-project group (management level) and schoolBeat advisors were identified as schoolBeat-stakeholders. Professionals participating in the regional youth meeting of public servants or the meeting of aldermen responsible for local and regional youth policy were included in the stakeholder group as well.

Fourteen of the 55 stakeholders were invited to participate in a semi-structured interview. In addition, three influential stakeholders who did not participate in the survey and who were identified by the project management as stakeholders with a presumed negative attitude towards the schoolBeat-alliance, were approached to be interviewed as well. This included an alderman of one of the smaller municipalities, a school director and someone from the support organizations. Of the interview group, four worked in the education sector, five for a support organization and three for a local or regional government.

\section{Measurement}

For the quantitative part, a survey was developed based on a self-evaluation survey for change managers of collaborative processes in primary health care using the original explorative research model [43]. The questionnaire was adjusted to reflect the constructs of the DISC-model and to focus explicitly on the whole-school health collaboration studied. A collaboration expert and a healthy school expert tested face validity of the questionnaire regarding its fit with whole-school health collaboration and the DISC-constructs. The questionnaire was improved on the basis of their suggestions. This was followed by a pre-test among four participants of a youth prevention alliance in a different region. The used instrument is available in Dutch only [see Additional file 1]. The survey consisted of 22 scales operationalizing all the main concepts from the DISC model (see Table 1) with 3 to 8 items. Except for the dichotomous items in the existing-collaborations a five point scale was used ( 1 being 'totally disagree' and 5 being 'totally agree'). Table 2 reports the number of items and the Cronbach's alpha of each scale. The actual instrument is in Dutch (see Appendix).

The interviews were semi-structured to address all constructs of the DISC-model and lasted one hour on average, covering all 22 scales. Where survey participants had presented the researchers with unexpected or unclear answers in the questionnaires, this was addressed in more detail in the interview. After asking the participants for permission, all interviews were taped and written down. Because there were only twelve participants involved, the interviews were analyzed manually. The transcriptions of the interviews were categorized in the clusters of the DISC-mode and quotations were labeled due to the cluster it referred 


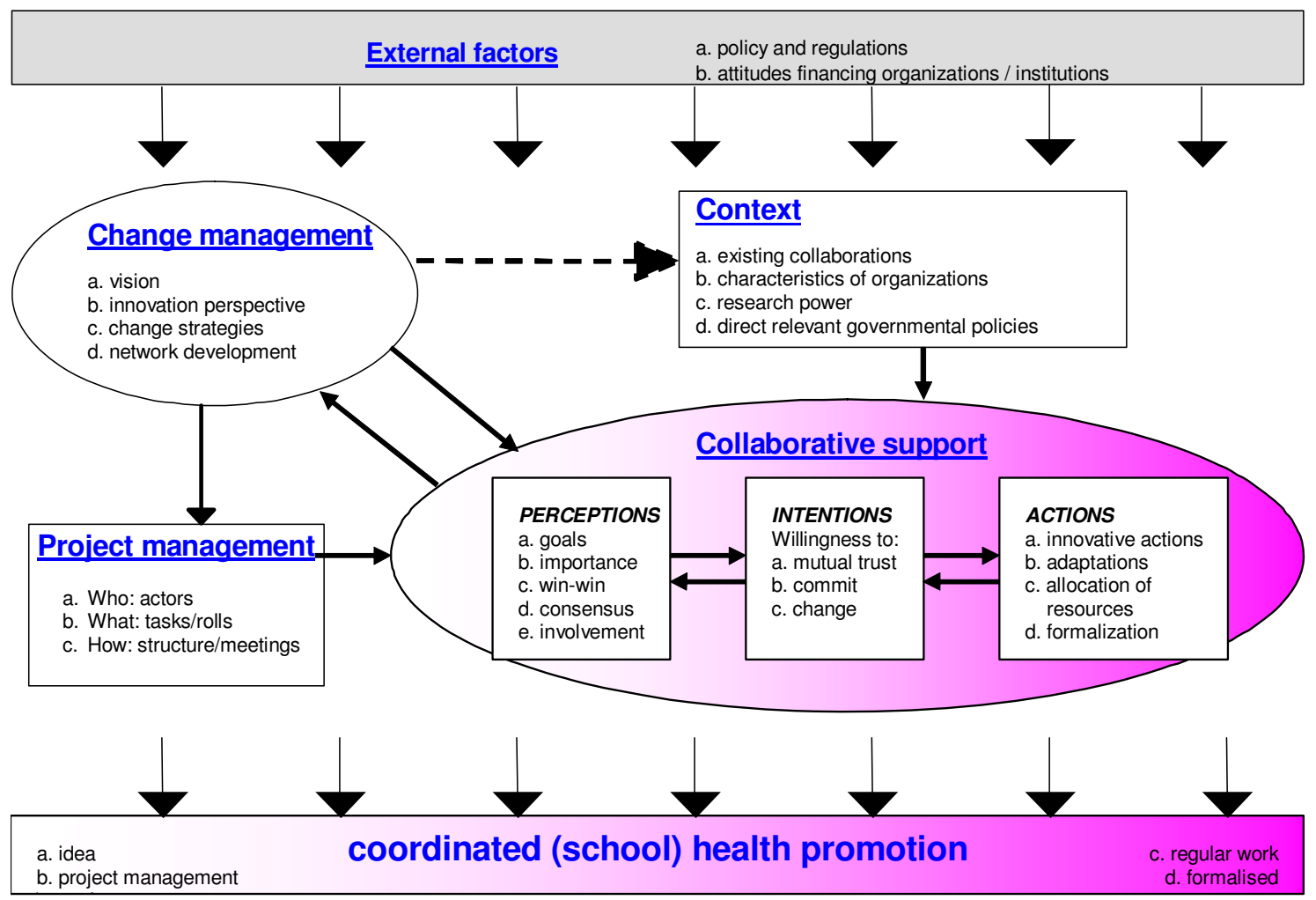

Figure I

The Dlagnosis of Sustainable Collaboration (DISC) model.

to. Matching quotations on the same questions were counted and finally all quotations of the participants were summarized and described by each cluster. Additionally, documents such as minutes of meetings, project descriptions and correspondence with schools and local and regional governments were analyzed based on the DISCmodel as well.

\section{Statistical analyses}

Cronbach's alpha was calculated for the scales operationalizing the distinct DISC-constructs (Table 2). For scales with only two items Pearson Correlation was calculated. We accepted a reliability score of 0.60 or above because of the explorative nature of the case study and the relative low number of possible participants in the survey.

Analysis of variance was conducted to test for differences on the DISC-constructs between stakeholders from the education sector, the public sector and the support sector.
Where differences among the means were significant $(\mathrm{p}<$ $0.05)$ or a trend was observed $(\mathrm{p}<0.10)$, the Bonferroni test was used to test differences between groups. The transcribed interviews and retrieved documents were scored manually according to the definitions of the DISC-constructs (Table 1).

\section{Procedure}

The survey was sent out to 55 schoolBeat-stakeholders in May 2003, with a 4-week deadline. A letter providing information on the aim of the study and confidentiality of individual answers accompanied the survey to fulfill informed consent requirements. The same information was provided with the invitation for the interviews. Semistructured interviews were conducted during autumn 2003, following up on results and questions risen from the document analysis and the first analysis of the surveyresults. Approval by an ethical committee was not required for this non-medical study. 
Table 2: Reliability, average and analyses of variance results per scale distinguishing sum-scores between public health, education and public service stakeholder-groups

\begin{tabular}{|c|c|c|c|c|}
\hline DISC-construct & Number of items & Cronbach's Alpha' & Mean (SD) & $\mathrm{F}$ \\
\hline \multicolumn{5}{|l|}{ External factors } \\
\hline - Policy and regulations & 3 & 0.48 & - & - \\
\hline - Attitudes of financing organizations & 4 & 0.74 & $2.68(0.89)$ & 0.16 \\
\hline \multicolumn{5}{|l|}{ Context } \\
\hline - Existing collaborations & 3 & 0.31 & - & - \\
\hline - Organizational characteristics & 8 & 0.61 & $3.7 I(0.50)$ & $3.27^{0}$ \\
\hline - Research power & 3 & 0.76 & $3.32(0.82)$ & 0.63 \\
\hline - Relevant policies & 4 & 0.75 & $2.95(0.78)$ & 1.18 \\
\hline \multicolumn{5}{|l|}{ Change management } \\
\hline - Vision & 3 & 0.79 & $4.28(1.00)$ & 0.02 \\
\hline - Innovation perspective & 6 & 0.60 & $3.89(0.42)$ & 1.13 \\
\hline - Change strategies & 4 & 0.67 & $4.01(0.55)$ & $10.49 * *$ \\
\hline - Network development & 4 & 0.65 & $4.07(0.55)$ & $4.94 *$ \\
\hline Project management & 5 & 0.87 & $3.29(0.8 \mathrm{I})$ & $4.69 *$ \\
\hline \multicolumn{5}{|l|}{ Collaborative support: } \\
\hline \multicolumn{5}{|l|}{ - Perceptions } \\
\hline h Goals & 9 & 0.90 & $4.39(0.59)$ & 0.63 \\
\hline h Importance/win-win & 4 & 0.84 & $3.84(0.75)$ & 1.23 \\
\hline${ }_{\mathrm{h}}$ Consensus & 5 & 0.82 & $3.82(0.72)$ & 0.27 \\
\hline h Involvement & 5 & 0.64 & $3.83(0.61)$ & 1.41 \\
\hline \multicolumn{5}{|l|}{ - Intentions } \\
\hline $\mathrm{h}$ Willingness to trust & 3 & 0.69 & $4.10(0.62)$ & 0.29 \\
\hline h Willingness to commit & 4 & 0.69 & $3.31(0.74)$ & $4.47^{*}$ \\
\hline $\mathrm{h}$ Willingness to change & 4 & 0.52 & - & - \\
\hline \multicolumn{5}{|l|}{ - Actions } \\
\hline h innovative actions \& adaptations & 5 & 0.67 & $2.86(0.79)$ & $3.98 *$ \\
\hline $\mathrm{h}$ resources & 2 & 0.40 & - & - \\
\hline h formalization & 2 & 0.33 & - & - \\
\hline Coordinated School Health Promotion & 8 & 0.90 & $3.53(0.66)$ & 1.27 \\
\hline
\end{tabular}

$* *=p<0.01 ; *=p<0.05 ; 0=p<0.10$

I For scales with two items, Pearson's correlation coefficient is presented.

\section{Results}

Of the 55 stakeholders invited to fill in the DISC-survey, 17 out of 19 people responded from the education sector (90\% response), 17 out of 19 from the support organizations (90\% response) and 8 out of 17 from the local and regional government (47\% response). Overall response amounted to $76 \%$. For the interviews, 12 persons of the 14 approached agreed to be interviewed.

Reliability analyses of the survey revealed that five scales were not sufficiently reliable: the policy and regulations scale, the existing-collaborations scale, the willingness to change scale, the resources scale and the formalization scale. These scales and their items were not included in further analyses. The reliability coefficients, averages per construct and the results of the analyses of variance per construct are presented in Table 2.

Table 2 shows relative low scores $(<3)$ for the perceived attitudes of financing organization scale (external factorsconstruct), relevant policies (context-construct) and innovative actions and adaptations (actions construct). The innovative actions and adaptations scale showed significant differences between the groups, with education stakeholders perceiving most innovative actions and adaptations (Mean 3.33; SD 0.37) and public service stakeholders perceiving least innovative actions and adaptations (Mean 2.11; SD 0.54).

Relative high scores $(>4)$ were found for three of the four scales in the change management construct with the 
change strategies and network development scales indicating significant differences between the groups (see Table 3). 'Goals' and 'willingness to trust' yielded also relative high scores without significant differences between groups.

Table 3 presents the constructs that revealed at least one significant difference between respondents of the three sectors: education, health and public service. Only for the first construct - organizational characteristics - differences found at item level are shown to illustrate the added value of further exploration in a DISC-study. The analyses revealed that stakeholders from the public sector indicated to be less committed to the schoolBeat initiative and to have incorporated fewer changes supporting wholeschool health promotion compared to their school and support partners. Additionally, they reported to be least open to innovation and to experience the most financial problems now or in the near future. Health promotion staff reported the highest level of intention to commitment while education staff reported the highest level of innovative actions and adaptations. Participants from the education domain reported to be better staffed but also to experience more major organizational changes compared to the public service. The health promotion support staff involved experienced higher level of change strategies and project management compared to the education staff.

In this explorative phase, the interviews seemed to shed more light on specific opportunities and impediments of the collaboration studied. Project-related documentation, including goals and a project management structure, was combined with to the survey-results in preparation for the interviews. During the interviews it became apparent that stakeholders from the three sectors used different interpretations of the goals of the schoolBeat collaborative. Differences were related to the health promotion versus pupil care debate (i.e. 'Why talk about prevention when we have not enough support for our individual pupil care problems?'). From the education-stakeholders we learned that they were skeptical about yet another new approach, with mixed evaluations of previous attempts. Nonetheless, these education-stakeholders saw opportunities in linking the schoolBeat approach to a safe-school approach already operating in schools. They seemed keen on improvements in the whole-school pupil care continuum with policies changing towards full inclusive education. This means that children with special needs should be able to attend regular schools, like in the US and other Anglo-Saxon countries. This was somewhat contrary to what health promotion stakeholders' wished to achieve with the schoolBeat-approach focusing primarily for collaborative improvements in the health promotion end of the integral pupil care continuum.

Regarding the DISC-constructs, the interviews and document analysis provided additional insights. For example, those interviewed found it difficult to distinguish innovative actions from adaptations within the 'action'-construct. The results of the interviews and the document analyses regarding the schoolBeat-alliance combined are summarized per DISC-construct in Table 4.

Table 3: Significantly differing group averages regarding DISC-constructs

\begin{tabular}{|c|c|c|c|}
\hline DISC-construct & Education $(n=17)$ mean $(S D)$ & Health Promotion $(n=17)$ mean $(S D)$ & Public Service $(n=8)$ Mean $(S D)$ \\
\hline \multicolumn{4}{|l|}{ Context } \\
\hline - Organizational characteristics: & $3.92(0.49)^{\mathrm{a}}$ & $3.68(0.46)$ & $3.40(0.45)^{\mathrm{b}}$ \\
\hline h Open to innovation & $4.12(0.86)$ & $4.47(0.62)^{a}$ & $3.50(0.93)^{b}$ \\
\hline $\begin{array}{l}\text { h Fully staffed } \\
\text { (no long-standing vacancies) }\end{array}$ & $4.53(0.62)^{a}$ & $4.29(0.85)^{a}$ & $3.43(0.73)^{b}$ \\
\hline${ }_{\mathrm{h}}$ Major organization change processes & $4.47(0.80)^{a}$ & $4.24(0.83)$ & $3.38(1.30)^{b}$ \\
\hline $\begin{array}{l}\text { }{ }_{\mathrm{h}} \text { Financial problems now or expected } \\
\text { in the near future }\end{array}$ & $4.19(1.24)$ & $3.69(0.85)^{a}$ & $4.75(0.46)^{b}$ \\
\hline \multicolumn{4}{|l|}{ Change Management } \\
\hline - Change strategies & $3.72(0.39)^{\mathrm{a}}$ & $4.43(0.32)^{b}$ & $4.01(0.75)$ \\
\hline - Network development & $3.99(0.44)$ & $4.34(0.39)^{\mathrm{a}}$ & $3.69(0.80)^{b}$ \\
\hline Project Management & $2.91(0.78)^{\mathrm{a}}$ & $3.70(0.67)^{b}$ & $3.26(0.81)$ \\
\hline \multicolumn{4}{|l|}{ Collaborative Support } \\
\hline - Intentions: willingness to commit & $3.19(0.52)$ & $3.67(0.86)^{\mathrm{a}}$ & $2.83(0.60)^{\mathrm{b}}$ \\
\hline $\begin{array}{l}\text { - Actions: Innovative actions \& } \\
\text { adaptations }\end{array}$ & $3.33(0.37)^{\mathrm{a}}$ & $2.83(0.77)$ & $2.11(0.54)^{b}$ \\
\hline
\end{tabular}

Means with different superscripts are statistically different $(\mathrm{p}<0.05)$ 
Competitive feelings of one of the initial schoolBeat partners surfaced during the DISC-pilot. These feelings were a result of the decision by the municipalities to transfer their powers regarding the financing of certain types of school support to the schools (see Table 4). The employees of the partner providing the support involved, seemed to feel threatened by this decision. To those involved, it was not sure whether this was a temporary phenomenon that could be overcome with trust among the partners or that it would be a lasting complicating factor with possible destructive effects on the schoolBeat-alliance. Therefore, it was recommended to pay special attention to developments leading to a re-introduction of competition elements between collaborating partners. The competitive feelings should be recognized by all partners and discussed in the perspective of dealing with a complicating factor caused by external factors.

The interviews further suggest that education professionals were least positive about the schoolBeat-collaboration. Here it should be known that the preparation of the schoolBeat-alliance started in 2001 with representatives of support organizations and local communities. Discussions with the education sector started in 2002 at management level, followed by an introduction of the schoolBeat methodology late 2002, spring 2003 at the school level. Misconception regarding the schoolBeat-goals of the education stakeholders complicated this delayed start even more. As the education stakeholders were expecting an improvement on the whole pupil care continuum due to schoolBeat, they were in for a deception with the schoolBeat-methodology focusing on school health promotion and prevention only. Hence, this provides room for improvement when the schoolBeat-alliance continues to involve education-representatives and to work towards shared goals.

A summary of the combined results of the DISC-pilot, with recommendations for improvement of the collaborative schoolBeat-related processes was forwarded to the schoolBeat project team. The recommendations included extending the project management over a longer period of time; strengthening communication with policy-makers; providing a communication boost regarding the proposed methodology and the extra financial possibilities targeting stakeholders' colleagues; further development and clarification of the shared methodology itself; and intensifying information sharing among the key-stakeholders. Although not all recommendations could be carried out straight away due to a variety of constraints, they were all accepted as intermediate goals for the alliance by the schoolBeat-partners.

\section{Discussion}

In this study we took up the challenge to learn from previous health-related collaborations $[10,35,44]$, and the diagnostic models used. Based on a literature review and practical experiences, we reshaped and extended the WIZDIZ-model into the DISC-model: diagnosis of sustainable collaboration. We explored the use of the DISC-model at an early stage in a collaborative and incremental process developing a comprehensive and tailored strategy for whole-school health promotion. Our aim was to provide a description of the current state of affairs regarding the collaboration in order to enable the selection and implementation of suitable change strategies.

The DISC-analysis provided us with a cross-sectional picture of a complex phenomenon: an intersectoral health promotion alliance including health/welfare, education and government. We found that involving stakeholders from the three groups involved as well as using multiple data sources complemented the picture created. It seemed to increase validity of the findings.

The DISC-model provides a comprehensive overview of factors involved in inter-agency collaborations. Especially the qualitative strand of the study seemed to provide the most specific insights into the current status of the collaboration. This should not be limited to document analyses only as this may not provide insight into disquiet among partners or possible other - not formally reported - negative aspects of the current status of a collaborative process $[8,45,46]$. For example, in the DISC-survey 'research power' did not reveal significant differences between groups based on survey-data, where document analysis did manage to provide useful information on the differences between stakeholder groups regarding this construct (see Table 4).

Our study clearly supports the value of using a systematic approach to monitoring the state of the art of interorganizational collaboration. Up-to-date information regarding windows of opportunity as well as impediments for collaborative change revealed by DISC-monitoring enhanced the selection of suitable strategies for collaborative problem solving.

To enable the use of DISC-based monitoring in other alliances that lack support of a professional research team, a short DISC-checklist for the project management would be useful similar to the previous developed for the WIZDIZ-model [47]. As the added value seemed to come from including different perspectives on the collaborative process, project managers using such a checklist should be encouraged to ensure representative stakeholder-input. Especially stakeholders from domains least familiar to the 
Table 4: Results of the DISC-analyses based on the transcribed interviews and document analysis

\begin{tabular}{|c|c|c|c|}
\hline & Education & Health Promotion & Government \\
\hline External factors & $\begin{array}{l}\text { Policies and regulations } \\
\text { Inclusive education: this puts a strain on } \\
\text { individual pupil care in regular schools } \\
\text { inhibiting attention for health promotion and } \\
\text { prevention at group level } \\
\text { Attitudes financing bodies } \\
\text { Lump sum financing for schools } \\
\text { Additional finances for pupil care in schools in } \\
\text { deprived areas }\end{array}$ & $\begin{array}{l}\text { Policies and regulations } \\
\text { - } \\
\text { Attitudes financing bodies } \\
\text { - Introduction of free market mechanisms in } \\
\text { health promotion and welfare feeds feelings of } \\
\text { competition among partners, especially at the } \\
\text { advisory level }\end{array}$ & $\begin{array}{l}\text { Policies and regulations } \\
\text { - Decentralization of tasks and regulations } \\
\text { from national to regional and local } \\
\text { governments }\end{array}$ \\
\hline Context & $\begin{array}{l}\text { Existing collaborations } \\
\text { - A collaborative history with youth health } \\
\text { care and youth monitoring with limited results } \\
\text { so far } \\
\text { - For schools in deprived areas a collaborative } \\
\text { history with youth welfare with mixed } \\
\text { evaluations } \\
\text { - Safe schools working group with municipality, } \\
\text { police, justice and public health } \\
\text { Organizational characteristics } \\
\text { - Autonomy of teaching staff } \\
\text { - No planning and reporting of HP actions } \\
\text { Research power } \\
\text { - Not present locally } \\
\text { Relevant local policies } \\
\text { - Safe schools policy } \\
\text { - Youth welfare in schools }\end{array}$ & $\begin{array}{l}\text { Existing collaborations } \\
\text { - The public health institute has positive } \\
\text { collaborative experiences with all HP partners. } \\
\text { - Limited collaborative experiences exists } \\
\text { among the partners themselves } \\
\text { - Participation in safe schools working group } \\
\text { Organizational characteristics } \\
\text { - Innovation minded management } \\
\text { - Limited internal support for HP } \\
\text { Research power } \\
\text { - Around half of the HP organizations involved } \\
\text { have academic research experience. } \\
\text { Relevant local policies } \\
\text { - Youth welfare in schools as pilot welcomed } \\
\text { by schools } \\
\text { - Regional shared care networks for youth } \\
\text { policy }\end{array}$ & $\begin{array}{l}\text { Existing collaborations } \\
\text { - Negative experiences prevail with the } \\
\text { institute providing most of the schoolBeat- } \\
\text { leadership. } \\
\text { - Positive attitude towards another } \\
\text { schoolBeat-partner } \\
\text { - Neutral towards other parties involved. } \\
\text { - Coordinator of the safe schools working } \\
\text { group } \\
\text { Organizational characteristics } \\
\text { - Influenced by political changes } \\
\text { - Bureaucratic } \\
\text { Research power } \\
\text { - A lack of expertise and direct interest in } \\
\text { generating and using academic evidence. } \\
\text { Relevant local policies } \\
\text { - Regional shared care networks for youth } \\
\text { policy }\end{array}$ \\
\hline Change Management & $\begin{array}{l}\text { Innovation perspective } \\
\text { - Based on educational expertise } \\
\text { Change strategies } \\
\text { - Not actively applied } \\
\text { Network development } \\
\text { - Inclusion of leadership of a primary schools' } \\
\text { representative and a care coordinator would } \\
\text { be desirable }\end{array}$ & $\begin{array}{l}\text { Innovation perspective } \\
\text { - Based on empirical evidence combined with } \\
\text { existing expertise among partners } \\
\text { Change strategies } \\
\text { - Network meetings } \\
\text { - Education of HP staff } \\
\text { Network development } \\
\text { - More active support from HP management is } \\
\text { desired. }\end{array}$ & $\begin{array}{l}\text { Innovation perspective } \\
\text { - not clearly defined } \\
\text { Change strategies } \\
\text { - open for information regarding the } \\
\text { collaborative process } \\
\text { Network development } \\
\text { - wish to start sharing information with } \\
\text { members of local and regional politics }\end{array}$ \\
\hline Project management & $\begin{array}{l}\text { No participation of schools in the project } \\
\text { organization at this stage. }\end{array}$ & $\begin{array}{l}\text { Whom: actors } \\
\text { filled in by the HP organizations only } \\
\text { What \& How: tasks \& structure } \\
\text { described by the coordinator and agreed upon } \\
\text { by the management of partner organizations }\end{array}$ & $\begin{array}{l}\text { No official governmental participation } \\
\text { One civil servant participated in the project } \\
\text { group but started as education support staff } \\
\text { before changing jobs and was allowed by his } \\
\text { new employer to keep participating once } \\
\text { joining an education department at } \\
\text { municipality level. }\end{array}$ \\
\hline
\end{tabular}




\begin{tabular}{|c|c|c|c|}
\hline $\begin{array}{l}\text { Support } \\
\text { Perceptions } \\
\text { Intentions } \\
\text { Actions }\end{array}$ & $\begin{array}{l}\text { Perceptions: goals/importance } \\
\text { - Quality improvement } \\
\text { - Creation of a pupil care support continuum } \\
\text { Perceptions: win-win } \\
\text { - Workload sharing regarding pupil care with } \\
\text { organizations outside the school } \\
\text { - School health profiles add to internal school } \\
\text { assessments for planning purposes. } \\
\text { Perceptions: consensus } \\
\text { - Tailored support from a single point of } \\
\text { contact } \\
\text { - Unease regarding the attention not yet paid } \\
\text { to individual pupil care } \\
\text { Perceptions: involvement } \\
\text { - Direct involvement of public service is } \\
\text { missed by some } \\
\text { Intentions: willingness to trust } \\
\text { - Seems present based on previous } \\
\text { experiences with the HP partners } \\
\text { Intentions: willingness to commit } \\
\text { - Based on perceived added value most school } \\
\text { administrators are willing to commit } \\
\text { Actions: innovative actions and adaptations } \\
\text { - Appointment of prevention teams in the first } \\
\text { schools } \\
\text { - High level of participation in evaluation } \\
\text { Overall: sufficient }\end{array}$ & $\begin{array}{l}\text { Perceptions:goals/importance } \\
\text { - Quality improvement } \\
\text { - Strengthening HP within schools } \\
\text { - Creation of a HP support continuum } \\
\text { Perceptions: win-win } \\
\text { - Workload sharing provides a win to all HP } \\
\text { organizations involved } \\
\text { Perceptions: consensus } \\
\text { - Consensus is present regarding the basic } \\
\text { outline of the methodology } \\
\text { - Tension is present regarding specific elements } \\
\text { of the methodology } \\
\text { Perceptions: involvement } \\
\text { - Direct involvement of schools and public } \\
\text { service is missed by some } \\
\text { Intentions: willingness to trust } \\
\text { - Feelings of competition among HP advisors } \\
\text { and managers } \\
\text { Intentions: willingness to commit } \\
\text { - Moderate to high, with major differences } \\
\text { among organizations } \\
\text { Intentions: willingness to change } \\
\text { - Is present, but partners are keen on } \\
\text { experiencing some positive results first and do } \\
\text { not know yet what exact changes would be } \\
\text { necessary } \\
\text { Actions: innovative actions and adaptations } \\
\text { - Appointment of schoolBeat - support staff to } \\
\text { schools by the four key-partners } \\
\text { - Description of support options in unified } \\
\text { format by all partners } \\
\text { Overall: sufficient/good }\end{array}$ & $\begin{array}{l}\text { Perceptions: goals/importance } \\
\text { - Improvement of efficiency and quality of HP } \\
\text { and pupil care support } \\
\text { - Deleting overlap in HP support } \\
\text { Perceptions: win-win } \\
\text { - Unclear about the value for the municipalities } \\
\text { involved } \\
\text { Intentions: willingness to trust } \\
\text { - Benefit of the doubt based on the core ideas } \\
\text { of the collaborative subject: whole-school } \\
\text { health promotion } \\
\text { Intentions: willingness to commit } \\
\text { - Moderate, as long as requirements set at the } \\
\text { start are met } \\
\text { Actions: innovative actions and adaptations } \\
\text { - Nearly absent } \\
\text { - Limited participation in evaluation } \\
\text { Actions: resources } \\
\text { - The collaborative process needs to produce } \\
\text { a methodology which entails no additional } \\
\text { costs to local governments } \\
\text { Overall: sufficient/good }\end{array}$ \\
\hline Coordinated school health promotion & Idea - start of a project & $\begin{array}{l}\text { Main focus on project } \\
\text { (beyond idea phase) }\end{array}$ & $\begin{array}{l}\text { Main focus on project } \\
\text { (beyond idea phase) }\end{array}$ \\
\hline
\end{tabular}


project manager may provide the most useful input for collaborative change.

To test the DISC-model itself (for example by using structural equation modeling), more participants would need to be included. As the model focuses on collaborative processes, only those people can be asked to participate who are considered to be stakeholders in these processes. This limits the number of possible participants in such a study. To overcome this problem, it could be worthwhile to apply a more generalized survey to comparable alliances simultaneously. In our case it would be preferable to stay with whole-school health alliances in order to be able to work with comparable sets of stakeholders. Another option is turning the DISC-analyses into a longitudinal study, as suggested by Feinberg and colleagues regarding clarification of causal direction in network analysis [48]. As the collaborative process evolves over time, we expect DISC-analysis to reveal a flow in the model from the idea phase toward organizational routine as the collaborative process matures. This is in line with the ideas of Plsek and colleagues regarding complexity science in which they advocate treating organizations as complex, adaptive systems $[49,50]$. Nonetheless, we strongly believe that successful DISC-based analyses should never be conducted using a quantitative survey only.

A weak aspect of the DISC-survey was the assessment of the existing collaborations construct and the formalization construct. Available literature in health promotion is unclear on these topics $[48,51,52]$. For example is it closeness or number of relationships within the network that counts? And: what needs to be formalized as a requirement for sustainability? Or, what do participants actually mean when they talk about sustainability? A recent study by St. Leger indicated a wide variety of definitions of sustainability among participants in the same collaborations [52]. Further research in the area of sustainability is required.

The DISC-model does not state how to advance and improve the collaborative process. Based on the systematically gathered evidence, informed decisions are possible for further action by those involved $[17,45]$. In particular, those who are supposed to fulfill leadership tasks should be aware of the different DISC-constructs and current DISC-status of the alliance in order to do so. In our pilot, a literature search was conducted parallel to the DISCanalyses in order to provide evidence-based recommendations. For example the recommendation to extend the project management over a longer period of time was suggested by some of the interview participants but was also supported by recommendations of a support structure in current health promotion literature $[7,53]$. Additionally, as pointed out by Nutbeam policy makers do not make use of scientific evidence regularly [54]. Hence, it comes as no surprise that the DISC-analysis indicated that the 'research power' of the government is rather limited and that better communication with politicians is to be recommended here.

Tuckman's four-stage model of group development processes [In: [45]] - forming, storming, norming and performing - could add to the understanding of collaborative processes in health promotion. In the studied case, staff involved in the alliance from education, health promotion and government appeared to be in different developmental phases. The health promotion partners seemed to be in the storming phase in which some unease and conflict was present amongst each other. The education and governmental stakeholders were still in the forming phase of orientation and getting acquainted. Awareness of this aspect could help the leadership to prepare for the storming phase among these education and governmental stakeholders once they had moved through the initial getting-to-know-each-other-better phase. For the health promotion partners, time and effort needed to be spent on consensus seeking in order to advance their input in the collaborative process. Therefore, clarification of the developed methodology was one of the evidence-based recommendations as well.

Based on the first use of the DISC-model and additional literature searches, we modified the following elements of the model:

- the 'change-management' construct was changed into 'leadership' incorporating both individual leadership as well as collective leadership $[26,37,55]$. According to Weiss and colleagues this enables bridging diverse cultures and boundary-spanning functions as well as revealing and challenging assumptions that limit thinking and action [51].

- Being a continuum, the concepts of 'innovative actions' and 'adaptation' were combined into the concept 'changes' within the 'action'-construct.

- The subject of the collaboration (represented by the bottom bar of the model) was simplified into a continuum starting as an 'idea' and leading to a 'routine' in its most pure form $[33,56]$. This eliminates the term 'formalized' in the subject of the collaboration, being already included in the 'collaborative support - action' construct.

- Additionally, based on the stakeholder theory, which includes the community's notion of social responsibility, and the institutional theory [57], we introduce the concept of 'society values' as part of the external factors in the DISC-model. 


\section{Conclusion}

The DISC-model is more than just the sum of the different parameters provided in the literature on interorganizational collaboration, organization change, networking and setting-approaches such as trust, relationships between partners and interpersonal connections, project management (including identification of roles and responsibilities), leadership, flexibility in working practices, institutionalization $[3,5,26,37,41,45]$. DISC-analysis provides indications regarding the links between these parameters and - potentially - enabling the detection of change in the combined collaborative parameters over time.

Linking a simplified DISC-analysis to the evaluation of single interventions in (school) health promotion based on a collaborative effort, may add to the explanation of the results of such an evaluation study. Context assessments have been advocated in several recent (school) health promotion studies $[8,46,58]$. The DISC-analysis provides insight into the organizational context of the intervention and indications for the sustainability of such an intervention as well as indications for the transferability of the evidence provided. This is almost all about the organizations who will have to support and implement the intervention structurally. Hence, DISC-analysis could help preventing type III errors from occurring in effectiveness studies: a health promotion intervention supposedly proves to be ineffective when it is actually the management and implementation which fails [59].

With collaborative processes inevitably linked to health promotion, thorough analysis of these processes should be part of any participatory action research approach to enhance health promotion via intersectoral collaboration. The DISC-analysis model offers a promising comprehensive evaluation framework looking at the status of the collaborative process and its impact on the goals of the health promotion initiative. Further exploration of the proposed DISC-constructs is warranted as well as simplifications of its use.

\section{Abbreviations \\ DISC: DIagnosis of Sustainable Collaboration.}

\section{Competing interests}

The authors declare that they have no competing interests.

\section{Authors' contributions}

MTWL developed the DISC-model, conducted the surveypart of the study and drafted the manuscript. IMMV participated in the development of the DISC-model, contributed to the design of the study and helped draft the manuscript. RvdS conducted the interviews, participated in data analysis and in the revision of the article. HPS par- ticipated in the design of the study and helped to draft the manuscript. NKV contributed to the interpretations of data and revised the manuscript critically for important intellectual content. All authors read and approved the final manuscript.

\section{Additional material}

\section{Additional file 1}

The Dutch DISC-questionnaire. The Dutch DISC-questionnaire as used in the 2003 validation study.

Click here for file

[http://www.biomedcentral.com/content/supplementary/14712458-8-382-S1.doc]

\section{Acknowledgements}

This study received a grant from the Netherlands Organization for Health Research and Development (ZonMw Healthy Living grant 40 10.003). We thank dr. Maria Jansen for the acquisition of funding, initiation and support of the schoolBeat collaborative studied and $\mathrm{mr}$. Peter van Neer for his work in the application procedure of the DISC-survey.

\section{References}

I. Andis P, Cashman J, Oglesby D, Praschil R, Adelman H, Taylor L, Weist $M$ : A strategic and shared agenda to advance mental health in schools through family and system partnerships. International Journal of Mental Health Promotion 2002, 4:28-35.

2. De Leeuw E: The Sane Revolution. Health Promotion: Background, Scope, Prospects Assen/Maastricht: Van Gorkum; 1989.

3. Gray B: Collaborating: Finding common ground for multi-party problems San Francisco: Jossey Bass; 1989.

4. Allensworth DD: Building community support for quality school health programs. Health Educ 1987, 18:32-38.

5. Padgett S, Bekemeier B, Berkowitz B: Collaborative Partnerships at the State Level: Promoting Systems Changes in Public Health Infrastructure. Journal of Public Health Management \& Practice 2004, 10:25I-257.

6. Van Eyk H, Baum F: Learning about interagency collaboration: trialling collaborative projects between hospitals and community health services. Health \& Social Care in the Community 2002, 10:262-269.

7. Deschesnes M, Martin C, Jomphe Hill A: Comprehensive approaches to school health promotion: how to achieve broader implementation? Health Promot Int 2003, 18:387-396.

8. El Ansari W, Weiss ES: Quality of research on community partnerships: developing the evidence base. Health Educ Res 2006, 21:175-180.

9. De Caluwé L, Vermaak H: Leren veranderen. Een handboek voor de veranderkundige. [Learning to change. A manual for change-experts] 2nd edition. Deventer: Kluwer; 2006.

10. Van Raak AJA: Zorgvernieuwing: een kwestie van routine. Een studie naar de vorming van interorganisationele netwerken en naar systeemveranderingen in de thuiszorg vanuit interactionistisch perspectief. [Innovations in care: a matter of routine. A study into the development of inter-organizational networks and system changes in home care from an interactionistic perspective]. Maastricht University; 1998.

II. Cummings TG, Worley CG: Organization Development and Change 7th edition. Mason, Ohio: South-Western College Publishing; 200I.

12. De Caluwé L, Vermaak H: Leren veranderen [Learning to change] Ist edition. Alphen aan den Rijn: Samsom; 1999.

13. Leurs MTW, Mur-Veeman IM, Schaalma HP, De Vries NK: Integrale samenwerking gaat verder dan de samenwerking tussen professionals: introductie van het DISC-model [Integrated collaboration continues beyond professional collaboration: introduction of the DISC-model]. TSG 2003, 81:369-372. 
14. De Caluwé L, Vermaak H: Learning to change Thousand Oaks: Sage Publications; 2003.

15. Leurs MTW, Jansen MWJ, Schaalma HP, Mur-Veeman IM, De Vries NK: The Tailored Schoolbeat-Approach: New Concepts for Health Promotion in Schools in The Netherlands. In The Health Promoting School: International Advances in Theory, Evaluation and Practice Ist edition. Edited by: Clift S, Jensen BB. Copenhagen: Danish University of Education Press; 2005:89-107.

16. Leurs MTW, Schaalma HP, Jansen MWJ, Mur-Veeman IM, St. Leger $\mathrm{LH}$, De Vries NK: Development of a collaborative model to improve school health promotion in the Netherlands. Health Promot Int 2005, 20:296-305.

17. Bartholomew LK, Parcel GS, Kok G, Gottlieb NH: Intervention mapping: designing theory- and evidence based health promotion programs. Mountain View, CA: Mayfield; 200I.

18. Peters L: De Netwerkbenadering - review [The network appraoch review] Woerden: NIGZ - Centre for Review and Implementation; 2001.

19. Leurs MTW, Jansen M, Ruiter M: Coordinated School Health Program: het 'Gezonde School Model' van de toekomst? [CSHP: the Healthy School Model of the future?]. Tijdschr Gezondheidswet 2002, 80:47I-473.

20. Peters LWH, Keijsers FEM: Kwaliteitscriteria voor gezondheidsbevorderende interventies in en rondom scholen: review en checklistontwikkeling [Quality criteria for school health promotion interventions: review and checklist development] Woerden: NIGZ - Centre for Review and Implementation; 2002.

21. Wallerstein N, Polascek M, Multrud K: Participatory evaluation model for coalitions: the development of system indicators. Health Promot Pract 2002, 3:35I-373.

22. St. Leger L, Nutbeam D: A model for mapping linkages between health and education agencies to improve school health. J Sch Health 2000, 70:45-50.

23. Jones J, Scanlon K, Raphael B, Hillin A, McAlpine R, Critchley A, Stonehouse R, McKie D, Kerr-Roubicek H, Meerman G: Health and Education Working Together: The New South Wales School-Link Initiative. International Journal of Mental Health Promotion 2002, 4:36043.

24. Lee A, Tsang C, Lee SH: A comprehensive "healthy schools programme" to promote school health: the Hong Kong experience in joining the efforts of health and education sectors. J Epi Community Health 2003, 57: I74-I77.

25. Goffin A, Fleming C, Grove J, Thompson R, Flentje J, Smith M, Alvaro $R$, Lock C, Philips J, Taylor J: Successful inter-agency collaboration: health agencies working together to better promote health in schools. World Conference on Health Promotion and Health education; 30 April 2004; Melbourne 2004.

26. Barrett L, Plotnikoff RC, Raine K, Anderson D: Development of measures of organizational leadership for health promotion. Health Educ Behav 2005, 32:195-207.

27. Bracht N: Health promotion at the community level: new advances 2nd edition. Thousand Oaks: Sage Publications, Inc; 1999.

28. Umble K, Steffen D, Porter JHG, Miller D, Hummer-McLaughlin K, Lowman A, Zelt S: The national Public Health Leadership Institute: evaluation of a team-based approach to developing collaborative public health leaders. Am J Public Health 2005, 95:64I-644.

29. Baldwin L, Abernethy P, Roberts L, Egan H: Forming, managing and sustaining alliances for health promotion. Health Promo J Australia 2005, 16:138-143.

30. Bartholomew LK, Parcel GS, Kok G, Gottlieb NH: Planning health promotion programs; an Intervention Mapping approach San Francisco, CA: Jossey-Bass; 2006.

31. Yin RK: Case study research. Design and methods 3rd edition. Thousand Oaks: Sage Publications; 2003.

32. Parsons C, Stears D: Evaluating health-promoting schools: steps to success. Health Educ 2002, 102:7-15.

33. Pluye P, Potvin L, Denis JL, Pelletier J: Program sustainability: focus on organizational routines. Health Promot Int 2004, 19:489-500.

34. Tijssen IMJG, Van Raak AJA, Mur-Veeman IM, Maarse JAM: Multiplecase studies. Enkele problemen bij de praktijk van het onderzoek naar zorgvernieuwingsprojecten [Multiple case studys. Some problems in the practise of care innovation research]. Tijdschrif voor Gezondheidswetenschappen 1992, 70:337-344.
35. Mur-Veeman I, Van Raak A: Interorganisational networks on the Dutch home health care market. Int J Health Plann Policy 1994, 9:245-258.

36. Van Raak A, Mur-Veeman I, Hardy B, Steenbergen M, Paulus A: Integrated Care in Europe. Description and comparison of integrated care in six EU countries Ist edition. Maarssen: Elsevier; 2003.

37. Daft RL, Noe RA: Organizational behavior Orlando: Hartcourt Inc; 2001 .

38. Katz D, Kahn R: The Social Psychology of Organizations New York: John Wiley \& Sons; 1966.

39. Morgan G: Images of organization Beverly Hills: SAGE Publications, Inc; 1986.

40. Ruland E, Van Raak A, Spreeuwenberg C, Van Ree J: Managing New Public Health: hoe zijn blijvende preventieve samenwerkingsverbanden te realiseren? Een agenda voor actie en onderzoek [How can preventive collaborations be realised? An agenda for action and research]. TSG 2003, 81:52-55.

41. Gillies P: Effectiveness of alliances and partnerships. Health Promot Int 1998, 13:99-120.

42. Fleuren MAH, Wiefferink $\mathrm{CH}$, Paulussen TGWM: Belemmerende en bevorderende factoren bij de implementatie van zorgvernieuwingen in organisaties [Inhiting and enhancing factors for the implementation of care innovations in organizations]. In Book Belemmerende en bevorderende factoren bij de implementatie van zorgvernieuwingen in organisaties [Inhiting and enhancing factors for the implementation of care innovations in organizations] (Editor ed.^eds.) City: TNO Preventie en Gezondheid; 2002.

43. Van Raak AJA, Mur-Veeman IM, Paulus ATG, Van Merode GG: WIZDIZ-99 diagnose-instrument integrale zorg [WIZDIZ-99. A shared-care diagnostic instrument] Maastricht: Maastricht University-BEOZ; 1999.

44. Ruland E, Van Raak A, De Vries NK, Van Ree J: Lessen van Hartslag Limburg: samenwerking in de openbare gezondheidszorg moet gestructureerd en gemanaged worden. In Tijd voor gezond gedrag Bevorderen van gezond gedrag bij specifieke groepen [Time for healthy behavior Promotion of healthy behavior among specific groups] Edited by: Jansen J, Schuit A, Van der Lucht F. Bilthoven: RIVM; 2002.

45. McMorris LE, Gottlieb NH, Sneden GG: Developmental states in public health partnerships: a practical perspective. Health Promot Pract 2005, 6:219-226.

46. Biglan A: Contextualism and the development of effective prevention practices. Prevention Science 2004, 5: I5-2I.

47. Van Raak AIA, Mur-Veeman IM, Paulus ATG, Van Merode GG: WIZDIZ-2005. Procesmanagement in public health - ontwerp, analyse \& verandering. Edited by: Bohlmeijer E, Ruland E, Van Raak A, Mur-Veeman I. Utrecht: Trimbos-instituut; 2005.

48. Feinberg ME, Riggs NR, Greenberg MT: Social networks and community prevention coalitions. The Journal of Primary Prevention 2005, 26:279-298.

49. Plsek P, Greenhalgh TT: The challenge of complexity in health care. BM/ 2001, 323:625.

50. Plsek $\mathrm{P}$, Wilson $\mathrm{T}$ : Complexity, leadership, and management in healthcare organisations. BMJ 200I, 323:746-749.

5I. Weiss ES, Miller R, Lasker R: Findings from the national study of partnership functioning: report to the partnerships that participated. In Book Findings from the national study of partnership functioning: report to the partnerships that participated. (Editor ed.^eds.) City: The Center for the Advancement of Collaborative Strategies in Health; 200I.

52. St. Leger L: Capacity building and sustainability in the youth intersect project by Brimbank-Melton PCP - an evaluation. In Book Capacity building and sustainability in the youth intersect project by Brimbank-Melton PCP - an evaluation (Editor ed.^eds.) City: Unpublished manuscript; 2005

53. Tones K, Green J: Health Promotion - Planning and Strategies London: SAGE publications; 2004.

54. Nutbeam D: Getting evidence into policy and practice to address health inequalities. Health Promot Int 2004, 1 9: I 37-| 40.

55. Day D: Leadership development: a review in context. Leadership Quarterly 2001, I I:581-6I3.

56. Dusenbury L, Hansen WB: Pursuing the course from research to practice. Prevention Science 2004, 5:55-60.

57. Van Raak A, Paulus A, Mur-Veeman I: Why do health and social care providers co-operate? Health Policy 2005, 74: I3-23.

58. St. Leger L: What's the place of schools in promoting health? Are we too optimistic? Health Promot Int 2004, 19:405-408. 
59. Tones K: Evaluating health promotion: a tale of three errors. Patient Education and Guidance 2000, 39:227-236.

\section{Pre-publication history}

The pre-publication history for this paper can be accessed here:

http://www.biomedcentral.com/1471-2458/8/382/pre pub

Publish with Bio Med Central and every scientist can read your work free of charge

"BioMed Central will be the most significant development for disseminating the results of biomedical research in our lifetime. " Sir Paul Nurse, Cancer Research UK

Your research papers will be:

- available free of charge to the entire biomedical community

- peer reviewed and published immediately upon acceptance

- cited in PubMed and archived on PubMed Central

- yours - you keep the copyright
BioMedcentral 